\title{
Standard Rate for Some Basic Stances in Karate.
}

\section{Amr Mohamed Saad Gaafar}

Department of Fighting and Water Sports, Faculty of Physical Education, Sadat City University, Egypt.

\begin{abstract}
The most fundamental postures in karate are (Zenkutsu Dachi and Kokutsu Dachi and Kiba Dachi) but karate references are almost devoid of the basis of a clear and unified model for these postures in line with all the players with their various physical variables, and all the trainers during their teaching these postures to novices they teach it depending on their background and the general specifications of the posture and that may take long time in teaching as well as player errors and the time spent in correction.

researcher found that these three postures involved in having a horizontal and vertical specific distance varies according to each postures and that determines its features and specifications, hence, appeared the idea of determining the vertical and horizontal distance for a specific posture of world champion and with knowledge of player height we can divide the player height on both vertical and horizontal distance which gives us two ratios that being considered as a sincere standard for a posture.
\end{abstract}

\section{Introduction:}

$\mathrm{M}$

asao Kaozhu refers that Karate stances are common to all types of Karate and Karate forms. They are far more than the dramatic combat postures they appear to be. They keep the body

\section{Figure 1}

Basic Karate 3 stances
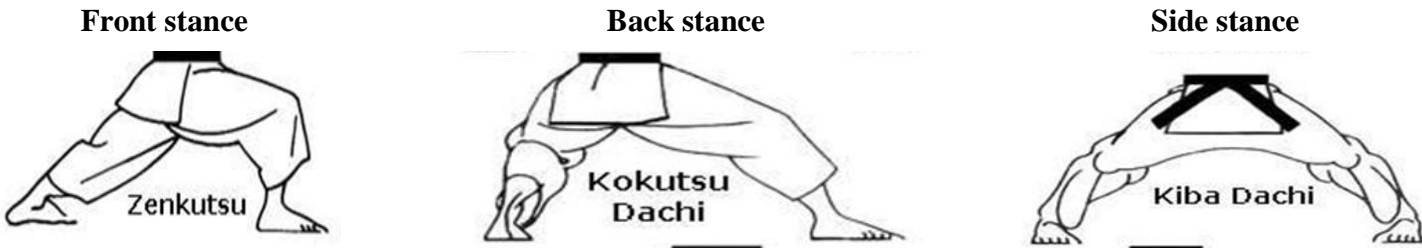

balanced and stable and allow attacks and defenses to be made with maximum effect.

The 3 main Karate Stances of Shotokan are:
Basic Karate moves become masterful techniques when the position of the feet, knees and hips all come together to create the right base. The move itself will determine which of the Karate stances is best for the posture.

$$
\text { (10: 1) }
$$

Ahmed Ibrahim (2005) mentioned that the posture is "Dachi-Kata" are the positions and distinct forms of the body taken by the player when demonstrating defensive and attacking techniques during the match and training for the sport of karate, and those postures are achieved through consistency and balance related to the case of the body during performing skills, whether defensive or offensive or transition from defense to attack, or vice versa. (1: 126127$)$

The researcher agrees with Ahmad Ibrahim in that there are many and varied postures through karate, and each posture has its distinctive characteristics that allow the 
horse ride stance "Kiba - Dachi "within the second group, which contains the basic postures.

Magdi Farouk mentioned that Zenkutsu Dachi is the most important posture learned for beginners, In this posture there is a distance between feet and hip goes down and front knee is bending over and the backbone is straight, it is one of the stances used in a lot of defense and attack postures which are found in the majority of Kata and the center of gravity of the bodyweight is $70 \%$ on the front foot and $30 \%$ on the rear foot.

\section{Table 1}

the relation of a load a back - front leg for Kokutsu Dachi

\begin{tabular}{|c|c|c|}
\hline No. & Authors & A front - back leg (\%) \\
\hline 1 & Pujic et. Al. 2003.(9) & $75: 25$ \\
\hline 2 & Kajtazi, 1997.(5) & $70: 30$ \\
\hline 3 & Oyama, 1977.(8) & $70: 30$ \\
\hline 4 & Nakayama, 1966.(6) & $70: 30$ \\
\hline
\end{tabular}

As he also mentioned that Kokutsu Dachi postures are very important indispensable when the players who achieved an advanced stage of the exercise and to do it you should put feet on one straight line and the distance is about $75 \mathrm{~cm}$ between the feet and the body weight carried at the back foot $70 \%$, and at the front foot $30 \%$ to carry the body, and the steadiness of the body must primarily on the back foot and the body is straight and perpendicular to the ground and in the last third of the distance between the feet and the anterior knee shouldn't be bent too much and this posture, the player can switch from defense to attack and vice versa very quickly (2: 168-169), (4:16)

Table 2

the values of a length of a posture Kokutsu Dachi according to the various authors

\begin{tabular}{|c|c|c|}
\hline No. & Authors & A front - back leg (\%) \\
\hline 1 & Pujic et. Al. 2003.(9) & 3 foot length \\
\hline 2 & Vracar, 1997.(7) & 2 shoulder widths \\
\hline 3 & Bozic \& Slovic, 1984.(3) & 2-3 hip width \\
\hline 4 & Nakayama, 1966.(6) & $80 \mathrm{~cm}$ \\
\hline
\end{tabular}

In the posture Kiba Dachi which is also called (horse riding stance) the feet are far apart, parallel and carry the body in middle of the distance between the feet, and the distance between the feet is twice as chest width and almost pushes knees to the outside and waist tight forward, this posture is considered with the stability and very highly used in Kata , and the player can shift from this position to any other position in any direction, and easily and quickly, and the center of gravity of the body in this posture midway between the feet. (2: 170)

The researcher agrees with what was said by Magdi Farouk (1996), Ahmed Ibrahim (2005), Masao Kaozhu and Dragan et. al. about importance of the three postures and specifications mentioned and also with the percentage distribution of body weight on both feet, but how can coaches achieve this ratio while training players using the naked eye ?! That is what the researcher is trying to avoid and he intends to provide an easier and practical way for application, by determining the vertical and horizontal distance to a posture according to each player individually according to his height.

It's evident from the previous view that no one talked about distance and the vertical mode and what percentage or amount of the distance decline in the level of height resulting from the knees bend while taking posture, or came upon the stated angles knees which produces from bending them during taking posture, but how can trainers achieve these angles in learning or training on the posture in karate field?! And when we look at the references that said horizontal distance we found that it had said the distance is not well defined, such as (2 shoulder width or 2-3 shoulder width or $80 \mathrm{~cm}$ or $90 \mathrm{~cm}$ ) and are comparative proportion that may cope with some of the players but do not with others.

Hence, the idea of this research appeared to the researcher, as there is a big agreement among those who work in the field of karate that the postures that are most fundamental and repeated over and over in karate are (Zenkutsu Dachi and Kokutsu Dachi and Kiba Dachi) and that they are applied in both types of competitions Kata and Kumite, no one disagrees on the importance of these three postures when teaching beginners karate and karate references are almost devoid of a clear basis and unified model which is clear specified for these postures which copes with all the players with their various physical variables, all the trainers during their teaching these postures to novices they teach them depending on their background and the general conditions of the posture and that may take long time in teaching as well as player's errors during his learning the posture and the time spent in correcting them.

Through the work of the researcher in the field of karate as lecturer of karate at the university and as a coach and as a player, researcher found that these three postures - and others - are involved in having a specific horizontal distance and vertical distance which vary according to each mode of this postures and that determines its features and specifications, Hence, appeared the idea of determining the vertical distance and the horizontal distance for a specific posture and with knowledge of player's height we can divide the player's height on both vertical and horizontal distance which gives us two ratios that being regarded as a sincere standard for a posture, then we can reach to the vertical and horizontal distance for the posture of any player by dividing his height to the 
two ratios of the posture needed, in order to save time , effort, and with accuracy, and in a method that combines theory and flexibility of application in the field .

\section{2-Research Objectives}

The research aims to:

$2 / 1$ to identify the vertical and horizontal distance of the player in posture Zenkutsu Dachi.

$2 / 2$ to identify the vertical and horizontal distance of the player in posture Kokutsu Dachi.

$2 / 3$ to identify the vertical and horizontal distance of the player in posture Kiba Dachi.

2/4 setting a fixed standard percentage each of the past posture in terms of the vertical and horizontal distance and the length of the player.

\section{3-Research questions:}

3/1 what is the vertical and horizontal distance of a player in posture Zenkutsu Dachi?

$3 / 2$ what is the vertical and horizontal distance of a player in posture Kokutsu Dachi?

$3 / 3$ what is the vertical and horizontal distance of a player in posture Kiba Dachi?

3/4 Can we calculate a standard ratio for each of the three posture in terms of the vertical and horizontal distance and the length of the player?

\section{4-Research terms:}

4/1 Horizontal distance: the distance between the player heels during taking any posture of karate. (Procedural)

4/2 Vertical distance: is the result of bending player's knees down to make any karate posture minus his actual length. (Procedural)
4/3 Ratio vertical distance: is the result of dividing the length of the player at the vertical distance of the posture. (Procedural)

4/4 Ratio of horizontal distance: is the result of dividing the length of the player at the horizontal distance of the posture. (Procedural)

\section{5-Previous studies:}

The researcher turned to search for studies, which focused on identifying the horizontal distance or vertical distance or the ratio of the vertical distance or percentage of the horizontal distance of any posture of the study, researcher did not find any but what was mentioned in table $\mathbf{1}$ and table 2 besides what was said by Ahmed Ibrahim (2005), Magdi Farouk (1996) and Dragan et. al for General Specifications for the postures and distribution ratio of the body weight on the knees, and this within the limits of researcher knowledge.

\section{6-Research Methodology:}

The researcher used the descriptive approach which is suitable for research procedures.

\section{7-Areas of research:}

\section{7/1 spatial domain:}

The researcher has taken measurements of research variables at 6 th of October sport club.

7/2 the time domain:

Research variables have been taken on Monday 20/05/2014.

\section{7/3 the Participants:}

The sample was selected of karate players who have advanced positions in the championship of the Republic and registered in Egyptian Karate Federation Giza branch, from different age stages (16-12 years) and one world champion player (Luca Valdesi) and their data as shown in table 3 .

Table 3

Shows the research sample

\begin{tabular}{|c|c|c|c|c|c|c|c|}
\hline Community & $\begin{array}{c}\text { world } \\
\text { champion }\end{array}$ & $\begin{array}{l}\text { under } 16 \\
\text { years }\end{array}$ & $\begin{array}{l}\text { under } 12 \\
\text { years }\end{array}$ & $\begin{array}{c}\text { Players } \\
\text { achieved } \\
\text { world 's first } \\
\text { position }\end{array}$ & $\begin{array}{c}\text { Players } \\
\text { achieved 1st } \\
\text { Republic } \\
\text { position }\end{array}$ & $\begin{array}{c}\text { Players } \\
\text { achieved 2nd } \\
\text { Republic } \\
\text { position }\end{array}$ & $\begin{array}{c}\text { Players } \\
\text { achieved 3rd } \\
\text { Republic } \\
\text { position }\end{array}$ \\
\hline $\begin{array}{c}13 \\
\text { players }\end{array}$ & $\begin{array}{c}1 \\
\text { player }\end{array}$ & $\begin{array}{c}4 \\
\text { players }\end{array}$ & $\begin{array}{c}8 \\
\text { players }\end{array}$ & $\begin{array}{c}1 \\
\text { players }\end{array}$ & $\begin{array}{c}4 \\
\text { players }\end{array}$ & $\begin{array}{c}2 \\
\text { players }\end{array}$ & $\begin{array}{c}6 \\
\text { players }\end{array}$ \\
\hline
\end{tabular}




\section{7/4 Conditions of choosing research sample:}

7/4/1 players should be registered for the Egyptian karate Federation.

7/4/2 players should be from different age stages.

$7 / 4 / 3$ players should be holders of advanced positions in the championship of the Republic.

7/4/4 one player holds a world championship first position. (Determined by researcher)

\section{8 - Data collection tools:}

8/1 tape measure.

$8 / 2$ players data collection forms.

8/3 PC for data processing.

8/4 Postures photos for the world champion.

\section{9 - Research procedures:}

9/1 the researcher meant to select a sample of differences in age and heights, to prove that neither age length affects

the ratio of vertical and horizontal distance of the postures, while there is an obvious correlation between the length of the player and the vertical distance and the horizontal distance of its own postures, as shown in table4.

9/2 the researcher collected players data of the basic postures (Zenkutsu Dachi - Kokutsu Dachi - Kiba Dachi).

9/3 the researcher concluded the vertical and horizontal ratio distance of each three basic postures for the world champion (Luca Valdesi) and take it as a criterion or slandered ratio.

9/3 the researcher calculated that, dividing the length of each player on the horizontal distance and vertical distance of his own posture measurements, and determining the percentage applied to each of them compared to the rates of basic postures for the world champion (Luca Valdesi) table 5 .

9/4 the researcher determined horizontal and vertical distance which supposed to be taken by the research players sample in their own basic postures to be the same level of performance of world champion table 6.

Table 4

the correlation coefficient between the lengths of the players and the horizontal and vertical distance of their own postures $\quad \mathrm{N}=13$

\begin{tabular}{|c|c|c|c|c|}
\hline \multicolumn{2}{|c|}{ Variables } & average & $\begin{array}{c}\text { standard } \\
\text { deviation }\end{array}$ & $\begin{array}{c}\text { correlation } \\
\text { coefficient }\end{array}$ \\
\hline \multirow{2}{*}{ Zenkutsu Dachi } & horizontal distance & 89.23 & 10.61 & 0.927 \\
\cline { 2 - 5 } & vertical distance & 123.96 & 10.87 & 0.967 \\
\hline \multirow{2}{*}{ Kokutsu Dachi } & horizontal distance & 88.46 & 10.58 & 0.824 \\
\cline { 2 - 5 } & vertical distance & 125.62 & 14.57 & 0.934 \\
\hline \multirow{2}{*}{ Kiba Dachi } & horizontal distance & 90.35 & 12.68 & 0.934 \\
\cline { 2 - 5 } & vertical distance & 124.27 & 13.65 & 0.932 \\
\hline
\end{tabular}

It's evident from the data in table (4) which meant to find the correlation coefficient between the lengths of the players and the horizontal and vertical distance of their own postures, that there is a correlation coefficient between ( 0.824 to 0.967$)$, and this value is greater than the value of (T) spreadsheet, which confirms that there is a significant correlation between height and horizontal \& vertical distance of a posture. 
Table 5

shows the horizontal and vertical ratios for each player of the sample and the percentage compared to the champion of the world (Luca Valdesi)

\begin{tabular}{|c|c|c|c|c|c|c|c|c|c|c|c|c|c|c|c|c|c|c|c|}
\hline \multirow{3}{*}{ no } & \multirow{3}{*}{ 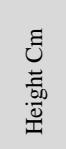 } & \multicolumn{6}{|c|}{ Zenkutsu Dachi } & \multicolumn{6}{|c|}{ Kokutsu Dachi } & \multicolumn{6}{|c|}{ Kiba Dachi } \\
\hline & & \multicolumn{2}{|c|}{ Distance } & \multicolumn{2}{|c|}{ Ratio } & \multicolumn{2}{|c|}{ Percentage } & \multicolumn{2}{|c|}{ Distance } & \multicolumn{2}{|c|}{ Ratio } & \multicolumn{2}{|c|}{ Percentage } & \multicolumn{2}{|c|}{ Distance } & \multicolumn{2}{|c|}{ Ratio } & \multicolumn{2}{|c|}{ Percentag } \\
\hline & & $>$ & \pm & $>$ & \pm & $>$ & \pm & $>$ & \pm & $>$ & \pm & $>$ & \pm & $>$ & \pm & $>$ & I & $>$ & \pm \\
\hline $\bar{*}$ & $\stackrel{\infty}{=} 0$ & $\stackrel{n}{\ddagger}$ & $\stackrel{\varrho}{\varrho}$ & 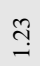 & 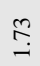 & $\frac{8}{0}$ & $\frac{8}{0}$ & ֻే & a & $\stackrel{8}{-}$ & $\stackrel{ \pm}{\underset{-}{ \pm}}$ & $\frac{8}{0}$ & $\frac{8}{0}$ & के & 三 & $\stackrel{I}{I}$ & $\stackrel{2}{2}$ & $\frac{8}{\circ}$ & $\frac{8}{0}$ \\
\hline$\sim$ & 守 & "ñ & a & $\stackrel{\stackrel{I}{I}}{ }$ & 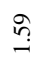 & $\frac{\bar{\partial}}{\circ}$ & ลू & ఫิ & 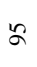 & $\stackrel{\unlhd}{I}$ & in & $\frac{\Delta}{\partial}$ & $\begin{array}{l}\stackrel{0}{\circ} \\
\stackrel{\circ}{\circ}\end{array}$ & 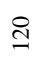 & $\sigma$ & 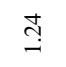 & ه্ & $\exists$ & $\frac{8}{\circ}$ \\
\hline$m$ & $\Xi \Xi$ & $\stackrel{\varrho}{-}$ & 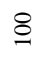 & $\stackrel{\unlhd}{I}$ & & $\frac{\bar{\sigma}}{\circ}$ & $\frac{\text { à }}{a}$ & 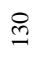 & $\stackrel{\overbrace{}}{\varrho}$ & $\stackrel{+}{\stackrel{I}{I}}$ & ?ִ & $\stackrel{\vec{\sigma}}{\vec{\sigma}}$ & $\begin{array}{l}\text { के } \\
\text { ó }\end{array}$ & 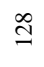 & 8 & ঙํㅛㅛ & ·্ & $\frac{m}{\partial}$ & $\frac{8}{\circ}$ \\
\hline+ & $\underline{8} \Xi$ & 昌 & $\stackrel{\infty}{\circ}$ & $\stackrel{\circ}{=}$ & 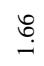 & 㕝 & $\stackrel{\circ}{\circ}$ & q & 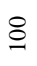 & $\stackrel{\circ}{=}$ & $\stackrel{8}{\circ}$ & $\frac{\sigma}{0}$ & $\begin{array}{l}\stackrel{a}{a} \\
\text { aे }\end{array}$ & $\begin{array}{l}n \\
0 \\
9\end{array}$ & $\stackrel{\infty}{\circ}$ & $\cong$ & به & $\frac{d}{0}$ & $\frac{8}{0}$ \\
\hline$n$ & $\stackrel{\infty}{\sim}$ ప & $\cong$ & $\frac{n}{\infty}$ & $\stackrel{\vartheta}{\leftrightarrows}$ & $\stackrel{\text { a }}{-}$ & à & $\stackrel{\circ}{\circ}$ & $\stackrel{0}{=}$ & $\infty$ & $\stackrel{\rightrightarrows}{\leftrightarrows}$ & $\stackrel{\circ}{\circ}$ & $\frac{8}{\circ}$ & $\stackrel{8}{\circ}$ & $\stackrel{\cong}{=}$ & $\infty$ & $\underset{\Im}{-}$ & م. & $\frac{\partial}{\circ}$ & $\frac{\partial}{0}$ \\
\hline 0 & ฮิ ઇ & $\cong$ & $\stackrel{\infty}{\curvearrowleft}$ & $\Xi$ & $\stackrel{n}{-}$ & $\stackrel{\circ}{\circ}$ & $\stackrel{\circ}{\partial}$ & $\stackrel{n}{\Xi}$ & $\therefore$ & $\stackrel{\circ}{=}$ & $\stackrel{\infty}{\circ}$ & $\frac{\sigma}{0}$ & ठ̊ & $\Xi$ & 尺 & $\stackrel{0}{=}$ & $\stackrel{+}{\underset{+}{+}}$ & $\frac{9}{9}$ & $\frac{\vec{a}}{0}$ \\
\hline r & $\cong \Xi$ & ले & $\stackrel{\infty}{\stackrel{\circ}{9}}$ & $\stackrel{\stackrel{I}{I}}{\longrightarrow}$ & $\stackrel{8}{\circ}$ & $\frac{\bar{\partial}}{\circ}$ & ๙่̊ & $\Xi$ & 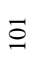 & 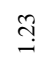 & $\underset{I}{F}$ & $\frac{m}{\vec{\sigma}}$ & $\stackrel{\circ}{\circ}$ & $\stackrel{\infty}{\sim}$ & $\stackrel{ \pm}{ \pm}$ & $-\stackrel{\text { I }}{\mathrm{c}}$ & مْ & $\frac{1}{\partial}$ & $\frac{\partial}{0}$ \\
\hline$\infty$ & $\frac{n}{\square}$ 号 & $\bar{I}$ & $\sigma$ & $\exists$ & $\stackrel{+}{\stackrel{5}{n}}$ & $\frac{a}{2}$ & 产 & $\stackrel{n}{\stackrel{2}{I}}$ & t & $\stackrel{\simeq}{=}$ & $\underline{n}$ & $\stackrel{\circ}{\circ}$ & $\begin{array}{l}\stackrel{0}{\circ} \\
\text { o̊ }\end{array}$ & $\Xi$ & d & $\stackrel{\vec{I}}{I}$ & $\stackrel{\vec{n}}{\longrightarrow}$ & $\frac{\infty}{\circ}$ & बे \\
\hline$a$ & 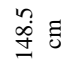 & $\tilde{I}$ & $\frac{n}{\dot{0}}$ & Iี & $\stackrel{R}{i}$ & $\stackrel{\partial}{\circ}$ & $\frac{\infty}{\partial}$ & $\tilde{\Xi}$ & $\infty$ & $\stackrel{\widetilde{I}}{\mathrm{I}}$ & I & $\stackrel{\Xi}{\partial}$ & $\stackrel{\circ}{\circ}$ & $\tilde{I}$ & "ू? & 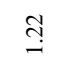 & ț & $\frac{8}{\circ}$ & $\stackrel{\infty}{\frac{0}{0}}$ \\
\hline 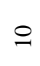 & $\frac{n}{m} \Xi$ & $\Xi$ & $\bar{\infty}$ & $\stackrel{\mathcal{I}}{\leftrightarrows}$ & $\stackrel{\widetilde{\sigma}}{\mathrm{T}}$ & $\bar{a}$ & ذั & $\stackrel{\varrho}{=}$ & 尺 & $\stackrel{9}{=}$ & $\stackrel{\bullet}{\circ}$ & $\frac{\mathrm{d}}{0}$ & $\frac{8}{\circ}$ & $\Xi$ & $\bar{\infty}$ & $\cong$ & مِّ & $\frac{8}{\circ}$ & $\frac{\hat{\sigma}}{0}$ \\
\hline$=$ & ڤి & $\stackrel{\infty}{=}$ & 尺 & $\stackrel{\infty}{=}$ & $\stackrel{\vec{\alpha}}{-}$ & $\stackrel{\circ}{\circ}$ & $\frac{\check{c}}{\circ}$ & తి & 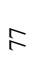 & $\stackrel{0}{=}$ & $\stackrel{\bar{\infty}}{-}$ & $\frac{\sigma}{0}$ & ठे & $\stackrel{\infty}{=}$ & $\therefore$ & $\stackrel{\infty}{=}$ & $\stackrel{\vec{\infty}}{\rightarrow}$ & $\frac{8}{\circ}$ & $\frac{\partial}{\partial}$ \\
\hline$\simeq$ & के & $\cong$ & $\stackrel{\infty}{\sim}$ & $\stackrel{9}{=}$ & $\stackrel{?}{\stackrel{2}{-}}$ & â & $\frac{\widetilde{\sigma}}{0}$ & $\Xi$ & ₹ & 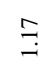 & $\stackrel{\Omega}{-}$ & $\frac{5}{0}$ & $\frac{8}{\circ}$ & $\stackrel{n}{=}$ & 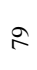 & $\stackrel{一}{\rightrightarrows}$ & $\stackrel{\Re}{\stackrel{n}{ت}}$ & $\frac{8}{\circ}$ & $\stackrel{+}{\frac{\partial}{0}}$ \\
\hline$\stackrel{m}{=}$ & छ & $\stackrel{n}{\infty}$ & $\infty$ & $\stackrel{\vartheta}{\rightleftarrows}$ & $\stackrel{\mathbb{N}}{-}$ & å & aे & $\begin{array}{l}n \\
\stackrel{\infty}{=}\end{array}$ & $\infty$ & $\stackrel{\vartheta}{=}$ & & $\frac{8}{\circ}$ & $\stackrel{a}{a े}$ & $\stackrel{\infty}{=}$ & $\infty$ & $\stackrel{\overbrace{}}{\leftrightarrows}$ & $\stackrel{\infty}{\stackrel{n}{?}}$ & $\frac{8}{\circ}$ & $\frac{\dot{\theta}}{0}$ \\
\hline
\end{tabular}

It's evident from the data in table (3) the standard ratio of postures ( Zenkutsu Dachi - Kokutsu Dachi - Kiba Dachi ) for world champion ( Luca Valdesi ) and the percentage for each player of the sample compared to him that player number (10) is equal to the world champion in the ratio of vertical distance for posture Kiba Dachi. 
Table 6

shows the ratios of the standard basic postures for the world champion and what should be the distance Horizontal and vertical for each player in the basic stances .

\begin{tabular}{|c|c|c|c|c|c|c|c|}
\hline \multirow{2}{*}{ No } & \multirow{2}{*}{$\begin{array}{l}\text { postures } \\
\text { distance }\end{array}$} & \multicolumn{2}{|c|}{ Zenkutsu Dachi } & \multicolumn{2}{|c|}{ Kokutsu Dachi } & \multicolumn{2}{|c|}{ Kiba Dachi } \\
\hline & & $\mathrm{V}$ & $\mathrm{H}$ & $\mathrm{V}$ & $\mathrm{H}$ & $\mathrm{V}$ & $\mathrm{H}$ \\
\hline$* 1$ & $\begin{array}{l}\text { world champion } \\
\text { ratio }\end{array}$ & 1.23 & 1.73 & 1.09 & 1.84 & 1.12 & 1.52 \\
\hline & $\begin{array}{c}\text { Player`s } \\
\text { length }\end{array}$ & V & $\mathrm{H}$ & V & $\mathrm{H}$ & V & $\mathrm{H}$ \\
\hline 2 & $149 \mathrm{~cm}$ & $121 \mathrm{~cm}$ & $86 \mathrm{~cm}$ & $137 \mathrm{~cm}$ & $81 \mathrm{~cm}$ & $133 \mathrm{~cm}$ & $98 \mathrm{~cm}$ \\
\hline 3 & $161 \mathrm{~cm}$ & $131 \mathrm{~cm}$ & $93 \mathrm{~cm}$ & $140 \mathrm{~cm}$ & $88 \mathrm{~cm}$ & $144 \mathrm{~cm}$ & $106 \mathrm{~cm}$ \\
\hline 4 & $163 \mathrm{~cm}$ & $133 \mathrm{~cm}$ & $94 \mathrm{~cm}$ & $150 \mathrm{~cm}$ & $89 \mathrm{~cm}$ & $146 \mathrm{~cm}$ & $107 \mathrm{~cm}$ \\
\hline 5 & $138 \mathrm{~cm}$ & $112 \mathrm{~cm}$ & $80 \mathrm{~cm}$ & $127 \mathrm{~cm}$ & $75 \mathrm{~cm}$ & $123 \mathrm{~cm}$ & $91 \mathrm{~cm}$ \\
\hline 6 & $129 \mathrm{~cm}$ & $105 \mathrm{~cm}$ & $75 \mathrm{~cm}$ & $118 \mathrm{~cm}$ & $70 \mathrm{~cm}$ & $115 \mathrm{~cm}$ & $85 \mathrm{~cm}$ \\
\hline 7 & $173 \mathrm{~cm}$ & $141 \mathrm{~cm}$ & $100 \mathrm{~cm}$ & $159 \mathrm{~cm}$ & $94 \mathrm{~cm}$ & $154 \mathrm{~cm}$ & $114 \mathrm{~cm}$ \\
\hline 8 & $141.5 \mathrm{~cm}$ & $115 \mathrm{~cm}$ & $82 \mathrm{~cm}$ & $130 \mathrm{~cm}$ & $77 \mathrm{~cm}$ & $126 \mathrm{~cm}$ & $93 \mathrm{~cm}$ \\
\hline 9 & $148.5 \mathrm{~cm}$ & $121 \mathrm{~cm}$ & $86 \mathrm{~cm}$ & $136 \mathrm{~cm}$ & $81 \mathrm{~cm}$ & $133 \mathrm{~cm}$ & $98 \mathrm{~cm}$ \\
\hline 10 & $131.5 \mathrm{~cm}$ & $107 \mathrm{~cm}$ & $76 \mathrm{~cm}$ & $121 \mathrm{~cm}$ & $71 \mathrm{~cm}$ & $117 \mathrm{~cm}$ & $87 \mathrm{~cm}$ \\
\hline 11 & $139.5 \mathrm{~cm}$ & $113 \mathrm{~cm}$ & $81 \mathrm{~cm}$ & $128 \mathrm{~cm}$ & $76 \mathrm{~cm}$ & $125 \mathrm{~cm}$ & $92 \mathrm{~cm}$ \\
\hline 12 & $137 \mathrm{~cm}$ & $111 \mathrm{~cm}$ & $79 \mathrm{~cm}$ & $126 \mathrm{~cm}$ & $74 \mathrm{~cm}$ & $122 \mathrm{~cm}$ & $90 \mathrm{~cm}$ \\
\hline 13 & $141 \mathrm{~cm}$ & $115 \mathrm{~cm}$ & $82 \mathrm{~cm}$ & $129 \mathrm{~cm}$ & $77 \mathrm{~cm}$ & $126 \mathrm{~cm}$ & $93 \mathrm{~cm}$ \\
\hline
\end{tabular}

It's evident from the data in table (3) the ratio of the standard basic postures (Zenkutsu Dachi - Kokutsu Dachi - Kiba Dachi) for world champion (Luca Valdesi) and what should be the horizontal and vertical distance for each player of research sample in basic stances.

\section{0 - Discussion of results:}

As what can be seen from the table above, the researcher concluded the ratio of horizontal and vertical distance of the world champion ( Luca Valdesi ) and took it as a standard for the basic postures - question (4) - by dividing the height of the player (Height of world champion is 178 $\mathrm{cm}$ ) on the vertical distance of the posture and then the horizontal distance for basic stances in this research, and this answers research questions, because now we know the horizontal and vertical distance for posture Zenkutsu Dachi - question (1) - and we know the vertical and horizontal distance for posture Kokutsu Dachi - question (2) - and we know the vertical and horizontal distance for posture Kiba Dachi - question (3) - .

The researcher also calculated the vertical and horizontal distance, which should be taken by local research sample by dividing the height of each of them on the standard ratio of the vertical distance and then dividing the length of each of them on the standard ratio of the horizontal distance, and result of this dividing expressing the horizontal and vertical distance that should be taken by the player for each posture of the basic stances as shown in table6.

The researcher adds that we can calculate the horizontal and vertical distance that must be taken by any player, whether novice or experienced in karate by knowing its length and standard fixed ratio of the posture.

Example: The player height is $182.5 \mathrm{~cm}$, what are the horizontal and vertical distances that should be taken up for postures Zenkutsu Dachi and Kokutsu Dachi and Kiba Dachi?

- By dividing the height of the player on the standard vertical \& horizontal ratio of posture Zenkutsu Dachi

Horizontal distance to posture Zenkutsu Dachi = $182.5 / 1.73=105.5 \mathrm{~cm}$

The vertical distance to posture Zenkutsu Dachi = $185.5 / 1.23=148.5 \mathrm{~cm}$

- By dividing the height of the player on the standard vertical \& horizontal ratio of posture Kokutsu Dachi

Horizontal distance to posture Kokutsu Dachi = $182.5 / 1.84=100 \mathrm{~cm}$

The vertical distance to posture Kokutsu Dachi = $185.5 / 1.09=167.5 \mathrm{~cm}$ 
- By dividing the height of the player on the standard vertical \& horizontal ratio of posture Kiba Dachi

Horizontal distance to posture Kiba Dachi $=182.5 / 1.52=$ $120 \mathrm{~cm}$

The vertical distance to posture Kiba Dachi $=185.5 / 1.12=$ $163 \mathrm{~cm}$

After determining these distances of these postures we can make a training or teaching it through tying an elastic band around the player heels after putting it at the wanted horizontal distance for the posture, and to do vertical distance we get two parallel posts connected with an elastic band after determining the vertical distance for the posture on the two posts, and the player making the posture between them and beneath the elastic band connected to the posts as shown in Figure 2.

Figure 2

illustrates how to develop or teach posture Zenkutsu Dachi after determining the vertical and horizontal distance for player.

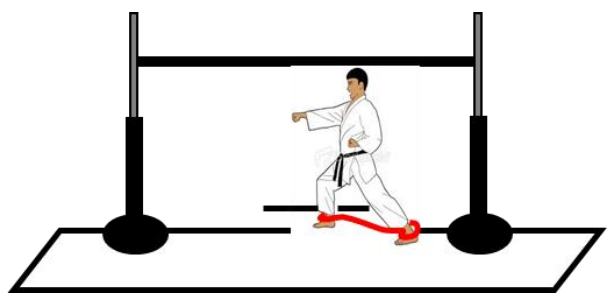

\section{1 - Recommendations:}

11/1 researcher recommends using standard ratios during teaching or training players on the basic karate postures.

11/2 researcher recommends trying to find a standard ratios of the different postures used in karate using the method used in this research.

\section{References}

\section{Arabic}

1- Ahmed

Mahmud

Ibrahim

\section{Foreign}

3- Bozic, J., \& : Karate for beginners, the Slovic, S.

4- Dragan D., Radivoj V., Ljubo J., steven P.

5- Kajtazi, V. institution for education and business of staff, Belgrade, 1984. : Biomechanical analysis of karate posture Kokutsu Dachi, Published thesis.

: karate Zagreb, personal edition,1997.

6- Nakayama, M. : Dynamic Karate, Fair press, 1966.p304

7- Vracar, N. : Karate teaching methods of trainings Banja Luka, printing firm, Branovic, 1997.

8- Oyama, M. $\quad$ : karate the grip, Mladost,1977.

9- $\quad$ Pujic M., $\quad$ Tactician model of an accuracy Pujic G. and the eleventh international grvenkovic, S. interdiscipline symposium Novi $\underline{\text { Sad, the university of Novi Sad }}$ and Novi Sad Marathon,2003.

\section{World Wide Web references}

10- 2/14/2013 12:01:20 PM http://www.dynamickarate.com/basic-karate-moves.html - 